This item was submitted to Loughborough's Research Repository by the author.

Items in Figshare are protected by copyright, with all rights reserved, unless otherwise indicated.

\title{
Effect of cement alkalinity on pore solution chemistry and chloride-induced reinforcement corrosion
}

PLEASE CITE THE PUBLISHED VERSION

PUBLISHER

(c) American Concrete Institute

\section{VERSION}

NA (Not Applicable or Unknown)

\section{LICENCE}

CC BY-NC-ND 4.0

\section{REPOSITORY RECORD}

Dehwah, Hamoud A.F., Simon A. Austin, and M. Maslehuddin. 2019. "Effect of Cement Alkalinity on Pore Solution Chemistry and Chloride-induced Reinforcement Corrosion". figshare.

https://hdl.handle.net/2134/4027. 
This item was submitted to Loughborough's Institutional Repository (https://dspace.lboro.ac.uk/) by the author and is made available under the following Creative Commons Licence conditions.

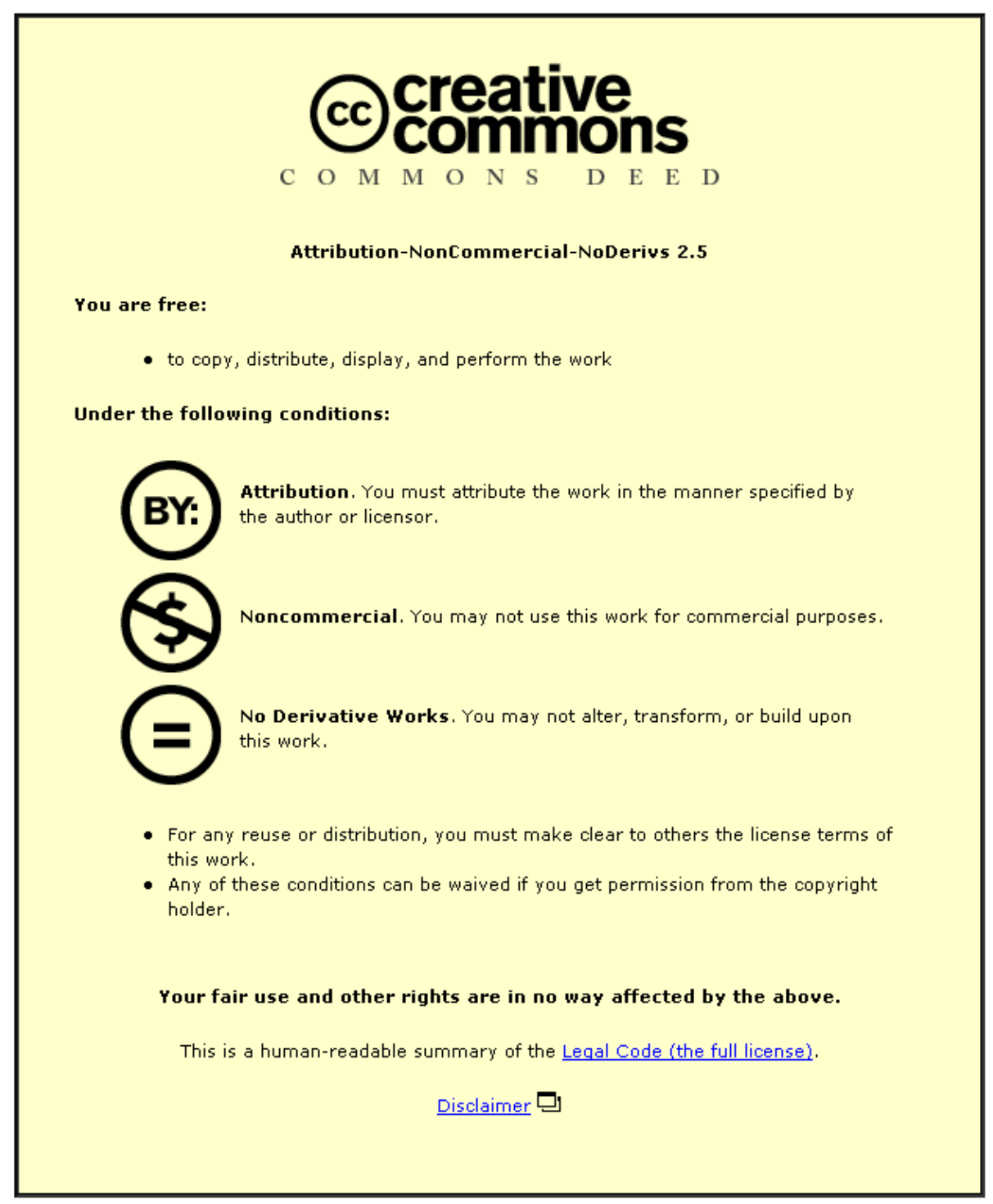

For the full text of this licence, please go to: http://creativecommons.org/licenses/by-nc-nd/2.5/ 


\title{
Effect of Cement Alkalinity on Pore Solution Chemistry and Chloride-Induced Reinforcement Corrosion
}

\author{
H. A. F. Dehwah*, M. Maslehuddin* and S. A. Austin** \\ * King Fahd University of Petroleum and Minerals, Dhahran 31261, Saudi Arabia \\ ** Loughborough University, Loughborough LE11 3TU, UK
}

\begin{abstract}
This paper reports the results of a study conducted to evaluate the influence of cement alkalinity on the pore solution chemistry and chloride-induced reinforcement corrosion in ordinary and sulfate resisting Portland cement concretes. To evaluate the influence of cement alkalinity on the pore solution chemistry, cement paste specimens were prepared and admixed with fixed quantity of sodium chloride and various dosages of alkalinity (in the range of 0.4 to $1.4 \% \mathrm{Na}_{2} \mathrm{O}$ equivalent). The pore solution was extracted and analyzed to determine the $\mathrm{OH}^{-}, \mathrm{Cl}^{-}$and $\mathrm{SO}_{4}^{--}$ concentrations. The influence of cement alkalinity on chloride-induced reinforcement corrosion was also assessed by measuring corrosion potentials and corrosion current density at regular intervals. The results indicated that the $\mathrm{OH}^{-}, \mathrm{Cl}^{-}$ and $\mathrm{SO}_{4}^{--}$concentrations of the pore solution increased with increasing alkali content of the cement. Further, the $\mathrm{Cl}^{-} / \mathrm{OH}^{-}$ratio decreased with increasing alkali content up to $0.8 \% \mathrm{Na}_{2} \mathrm{O}$ and then increased with a further increase in the alkalinity. Furthermore, an improvement in the corrosion-resistance of the SRPC and OPC concrete specimens was noted with increasing alkali content of cement. However, the highest improvement was noted when the alkalinity was $0.8 \% \mathrm{Na}_{2} \mathrm{O}$ equivalent.
\end{abstract}

Keywords: Alkalinity, Chloride, Corrosion, Corrosion potentials, corrosion current density and Pore solution. 


\section{Introduction}

Cement chemistry significantly influences the pore solution composition and hence the mechanisms of reinforcement corrosion. The two chemical properties of cements that affect its chloride-binding capacity are the $\mathrm{C}_{3} \mathrm{~A}$ content and alkalinity. While considerable research has been conducted on the effect of $\mathrm{C}_{3} \mathrm{~A}$ phase of cement on its chloride-binding capacity and reinforcement corrosion, meager data exist on the effect of alkalinity of cement on chloride-binding and pore solution chemistry. The influence of cement alkalinity on reinforcement corrosion is not very well documented and no data are available regarding the effect of cement alkalinity on time-to-initiation of reinforcement corrosion and corrosion current density in concrete. Limited studies [1-2] conducted to date have concentrated on the effect of cement alkalinity on the pore solution chemistry.

The alkaline pore solution of concrete protects the reinforcing steel from corrosion by forming a sub-microscopically thin protective film of gamma ferric oxide $\left(\gamma-\mathrm{Fe}_{2} \mathrm{O}_{3}\right)$ on the steel surface. However, high alkalinity of cement may adversely affect its chloride-binding capacity thereby influencing the kinetics of reinforcement corrosion. Few researchers [3-5] have reported a significant inhibiting effect of an alkaline pore solution environment on the chloride-binding capacity of cement. Page and Vennesland [3] reported a substantial decrease in the chloridebinding capacity of silica fume cements due to a resulting decrease in the alkalinity of the pore solution. Gunkel [4] has shown that the effect of alkali on reducing the chloride-binding of cement may be greater than that of the sulfate ions. Tritthart [5] has shown that cement alkalinity significantly influences the chloride-binding of cement and hence the free chlorides. 
According to Hausmann [6] both chloride concentration and alkalinity of the pore solution affect the corrosion process. Taking into account the concomitant effect of chloride and alkalinity, he suggested that the critical $\mathrm{Cl}^{-} / \mathrm{OH}^{-}$to be around 0.6. Gouda [7], using $\mathrm{pH}$ values of the electrolyte representative of the concrete pore solution, indicated that the threshold $\mathrm{Cl}^{-} / \mathrm{OH}^{-}$was 0.3 . Lambert et al. [8] investigated the relationship between $\mathrm{Cl}^{-} / \mathrm{OH}^{-}$and corrosion current density in various cements. Their investigation indicated that the passive conditions of steel in concrete, characterized by corrosion current density $\left(\mathrm{I}_{\text {corr }}\right)$ substantially lower than $100 \mathrm{nA} / \mathrm{cm}^{2}$, were maintained until a threshold $\mathrm{Cl}^{-} / \mathrm{OH}^{-}$ratio of approximately 3 was exceeded. There was a considerable scatter in the values of $\mathrm{I}_{\text {corr }}$ recorded at $\mathrm{Cl}^{-} / \mathrm{OH}^{-}$ratios in excess of 3 and even at $\mathrm{Cl}^{-} / \mathrm{OH}^{-}$ratios as high as 15 to 20 , there were instances of bars suffering no significant corrosion. Kayyali and Haque [9] emphasized the importance of $\mathrm{Cl}^{-}$ $/ \mathrm{OH}^{-}$threshold to predict the time to initiation of reinforcement corrosion. They provided charts giving safe regions of $\mathrm{Cl}^{-} / \mathrm{OH}^{-}$values for various concrete. According to their charts, a $\mathrm{Cl}^{-} / \mathrm{OH}^{-}$value of more than 0.6 , for concrete with admixed chloride is considered unsafe. Similarly, a $\mathrm{Cl}^{-} / \mathrm{OH}^{-}$value of greater than 3.0 for concrete exposed to external chloride is considered unsafe.

Mangat and Molloy [10] indicated that a universal threshold $\mathrm{Cl}^{-} / \mathrm{OH}^{-}$level is not applicable to all concrete. In their investigation, reinforcing steel corrosion was observed in the control matrix when the $\mathrm{Cl}^{-} / \mathrm{OH}^{-}$was 13 , while at values of 17 and 18 , in a silica fume cement concrete, reinforcement corrosion was insignificant. Similarly, minimal reinforcement corrosion was reported by Al-Amoudi et al. [11] in silica fume cement and blast furnace slag cement mortar specimens, placed in an aggressive sabkha (highly saline soil) environment, even at $\mathrm{Cl}^{-} / \mathrm{OH}^{-}$of 3.3 and 6.5 , 
respectively. Tests conducted by Arya et al. [12] also indicated that the uptake of chlorides is reduced to half when the storage of specimens was changed from $12.5 \mathrm{pH}$ environment (saturated calcium hydroxide solution) to a $\mathrm{pH}$ environment of 13.7 (0.5 $\mathrm{M} \mathrm{NaOH}$ solution). The inhibiting effect of high alkalinity on chloride binding has also been reported by Hussain [1]. Talib [2] investigated the effect of alkali content of cement on the chloride concentration in the pore solution. The proportions of unbound chlorides, in both plain and silica fume cements, increased with the alkali content of cement.

The high alkali content of cement while reducing the chloride-binding capacity of cement may also accelerate alkali-aggregate reaction, thereby enhancing reinforcement corrosion in the environments charged with chloride ions. However, one major contribution of the high alkalinity of cement is a reduction in the $\mathrm{Cl}^{-} / \mathrm{OH}^{-}$ ratio that controls the kinetics of reinforcement corrosion.

In the studies conducted so far, the effect of cement alkalinity on its chloride binding has been evaluated to a limited extent. The effect of cement alkalinity on reinforcement corrosion was evaluated by placing steel in electrolyte representative of concrete pore solution. However, the effect of cement alkalinity on reinforcement corrosion and the buffering action of an alkaline environment when chloride ions diffuse from the external environment have not been investigated.

This study was conducted to evaluate the effect of cement alkalinity on the pore solution chemistry, i.e., $\mathrm{OH}^{-}, \mathrm{Cl}^{-}$and $\mathrm{SO}_{4}^{--}$concentrations, and chloride-induced reinforcement corrosion in sulfate resisting and ordinary Portland cement concerts.

\section{Experimental Program}




\subsection{Pore Solution Chemistry}

\subsubsection{Materials and Specimen Preparation}

Cylindrical cement paste specimens, $49 \mathrm{~mm}$ in diameter and $75 \mathrm{~mm}$ high, were cast using sulfate resisting Portland cement (SRPC) and Portland cement (PC) with an effective water to cement ratio of 0.45 . The chemical composition of cements is shown in Table 1. All cement paste specimens were admixed with fixed quantity of sodium chloride $\left(0.8 \% \mathrm{Cl}^{-}\right.$by weight of cement $)$and the cement alkalinity was adjusted to $0.4,0.6,0.8,1.0,1.2$ and $1.4 \%\left(\mathrm{Na}_{2} \mathrm{O}\right.$ equivalent $)$. To obtain the required quantity of alkalinity or chloride concentration, analar grade of sodium hydroxide and sodium chloride salts were dissolved in the mix water, which was added gradually to the cement during mixing. The constituents were mixed in a blender till uniform consistency was obtained. The cement paste was poured into plastic cylindrical vials in two layers with appropriate consolidation to remove entrapped air. The vials were then tightly sealed and kept at a controlled laboratory temperature of $20 \pm 2{ }^{\circ} \mathrm{C}$ until testing. Three replicate specimens were cast from each batch.

\subsubsection{Pore Solution Extraction and Analysis}

The pore solution in the cement paste specimens was extracted using a highpressure pore solution expression device similar to that used by Longuet et al. [13] and Barneyback and Diamond [14]. This technique has the advantage that the pore solution can be extracted and its composition known. Though this is a tedious method, the pore solution so extracted has a uniform concentration, while this advantage is not available with other techniques, such as determining the pore solution composition by water or acid extraction. The pore solution was extracted after 100 days of casting. For this purpose, the specimen was placed on the 
base of a pore press and pressure was applied through the piston and gradually increased to a maximum of $150 \mathrm{MPa}$. This pressure was sustained until sufficient quantity ( 3 to $4 \mathrm{ml}$ ) of the pore fluid was recovered in a hypodermic syringe through the fluid drain located at the base of the apparatus. Care was taken to avoid undue exposure of the pore solution to air and it was stored in sealed plastic tubes till the time of analysis. The expressed pore solution was analyzed to determine $\mathrm{OH}^{-}, \mathrm{Cl}^{-}$and $\mathrm{SO}_{4}{ }^{--}$concentrations as described below.

The $\mathrm{OH}^{-}$concentration of the pore solution was evaluated by direct titration against nitric acid. For this purpose, 0.2 to $0.5 \mathrm{ml}$ of the pore solution was diluted with deionized water to $10 \mathrm{ml}$ and the $\mathrm{OH}^{-}$concentration was measured by direct titration against $0.01 \mathrm{M}$ nitric acid using phenolphthalein as an indicator. A burette with a least division of $0.02 \mathrm{ml}$ was used for titration. The actual molarity of the nitric acid was determined by titrating it against $0.01 \mathrm{M} \mathrm{NaOH}$.

The chloride ion concentration of the pore solution was assessed by the spectrophotometric method [15]. For this purpose, $0.2 \mathrm{ml}$ pore solution was diluted to $10 \mathrm{ml}$ with distilled water. To the diluted solution, $2 \mathrm{ml}$ ferric ammonium sulfate and $2 \mathrm{ml}$ mercuric thiocynate, saturated in ethanol, were added. The mixture was mixed slowly and continuously by shaking the beaker and then kept undisturbed for about 30 minutes before the absorption reading was taken on a Spectronic model UV21 spectrophotometer at a wave length of $460 \mathrm{~nm}$ against deionized water. The chloride concentration was computed using a computer programme that was based on a calibration curve prepared using a standard chloride solution. Some specimens were serially diluted to decrease the chloride concentration to less than $10 \mu \mathrm{g} / \mathrm{L}$. 
The sulfate concentration was determined using the spectrophotometric method outlined in standard methods for the analysis of water and wastewater, recommended by the American Water Works Association (AWWA) [16]. For this purpose, $0.5 \mathrm{ml}$ of the pore solution was diluted to $100 \mathrm{ml}$ using deionized water. To the diluted solution, the recommended buffer was added and absorption measured using a spectrophotometer at a wave length of $420 \mathrm{~nm}$. Barium chloride $\left(\mathrm{BaCl}_{2}\right)$ was then added to the solution and mixed by stirring for one minute. After thorough mixing, the solution was placed in the spectrophotometer and the absorption reading taken after 5 minutes. The sulfate concentrations were calculated from the net absorption using a calibration curve that prepared using a standard sulfate solution.

\subsection{Chloride-Induced Reinforcement Corrosion}

\subsubsection{Materials and Specimen Preparation}

To study the effect of alkalinity on chloride-induced reinforcement corrosion, reinforced concrete specimens were prepared and cement alkalinity was adjusted to $0.4,0.6,0.8,1.0,1.2$ and $1.4 \%\left(\mathrm{Na}_{2} \mathrm{O}\right.$ equivalent $)$ by adding the required quantities of sodium hydroxide. Analar grade sodium hydroxide was mixed with the mix water to obtain the required alkalinity. Reinforced concrete cylinders, $75 \mathrm{~mm}$ in diameter and $150 \mathrm{~mm}$ high, were cast using sulfate resisting Portland cement (SRPC) and ordinary Portland cement (OPC) with an effective water to cement ratio of 0.45 and cement content of $350 \mathrm{~kg} / \mathrm{m}^{3}$. Crushed limestone with a specific gravity of 2.43 and absorption of 3\% was used as coarse aggregates and dune sand with a specific gravity of 2.53 and absorption of $0.57 \%$ was used as fine aggregates. The coarse and fine aggregates were clean and free from all types of salts, dust and other fine particles. The volume of water in each mix was adjusted to compensate for the absorption 
of coarse and fine aggregates. All mixtures have the same water/cementitious ratio to be consistent.

The steel bars were cleaned and coated with cement paste and followed by an epoxy coating at the concrete-air interface and bottom of the bar in order to avoid crevice corrosion at these locations. The steel bars were cleaned mechanically with a silicon carbide paper, wherever necessary, and degreased with acetone prior to casting in concrete. The concrete specimens were cast in steel moulds. Before casting, the moulds were cleaned and slightly oiled to facilitate the demolding process. The $12 \mathrm{~mm}$ diameter steel bar was then fixed centrally at the middle of the mould providing a $25 \mathrm{~mm}$ clear cover at the bottom.

The concrete ingredients were mixed in a mechanical mixer and placed in the moulds in two layers by consolidation on a vibrating table. After casting, the specimens were covered with polyethylene sheets and allowed to cure at the laboratory temperature for 24 hours. The specimens were then demolded and cured in potable water maintained at $25{ }^{\circ} \mathrm{C}$ for 28 days. After this curing period, the specimens were dried by keeping them at room temperature for one week and then placed in plastic containers containing the test solutions.

\subsubsection{Exposure Solutions}

The concrete specimens were divided into six groups, each group consisted of three specimens from each cement. The specimens in each group were placed in solution containing $5 \% \mathrm{NaCl}$ and varying alkalinity as detailed in Table 2.

\subsubsection{Monitoring of Reinforcement Corrosion}


Reinforcement corrosion was evaluated by measuring corrosion potentials and corrosion current density ( $\left.\mathrm{I}_{\text {corr }}\right)$ at regular intervals. These techniques are nondestructive in nature and provide both quantitative and qualitative indication of reinforcement corrosion. While corrosion potentials provide a qualitative indication of reinforcement corrosion, particularly its initiation, corrosion current density measurements provide a quantitative measurement of the rate of reinforcement corrosion

Reinforced concrete specimens were partially immersed in the test solution. The level of the solution was adjusted, so that only 85 to $90 \mathrm{~mm}$ of the bottom of the specimen was in the solution. Measurements were conducted on three specimens representing similar mix composition and average values were reported. The corrosion potentials were measured using a saturated calomel reference electrode (SCE) and a high impedance voltmeter. The steel bar was connected to the positive terminal of the voltmeter while the reference electrode was connected to its negative terminal. The corrosion current density was measured using the linear polarization resistance method. In this technique, steel is polarized to $\pm 20 \mathrm{mV}$ of the corrosion potential and resulting current is measured and the slope of the potential-current curve at the open circuit potential is obtained. Corrosion current density is then calculated using the following formula proposed by Stern and Geary [17]:

$$
\mathrm{I}_{\mathrm{corr}}=\mathrm{B} / \mathrm{R}_{\mathrm{p}}
$$

Where:

$$
\begin{aligned}
& I_{\text {corr }}=\text { corrosion current density, } \mu \mathrm{A} / \mathrm{cm}^{2} \\
& \mathrm{R}_{\mathrm{p}}=\text { polarization resistance, } \mathrm{K} \Omega . \mathrm{cm}^{2}
\end{aligned}
$$




$$
\mathrm{B}=\frac{\beta_{a}^{*} \beta_{c}}{2 \cdot 3\left(\beta_{a}+\beta_{c}\right)}
$$

Where: $\beta_{\mathrm{a}}$ and $\beta_{\mathrm{c}}$ are the anodic and cathodic Tafel constants, $\mathrm{mV} / \mathrm{decade}$, respectively.

The Tafel constants are normally obtained by polarizing the steel to $\pm 250 \mathrm{mV}$ of the corrosion potential (Tafel plot). However, in the absence of sufficient data on $\beta_{\mathrm{a}}$ and $\beta_{\mathrm{c}}$, a value of $\mathrm{B}$ equal to $26 \mathrm{mV}$ for steel in active condition and $52 \mathrm{mV}$ for steel in passive condition is used [18]. In this investigation, Tafel constants of 120 mV/decade were used. In another study, Dehwah et al. [19] conducted potentiodynamic experiments on concrete specimens and the results indicated that, the Tafel constants are close to $120 \mathrm{mV} /$ decade. Lambert et al. [8] reported a good correlation between corrosion rate determined using these values and the gravimetric weight loss method.

\section{Results}

\subsection{Pore Solution Chemistry}

The $\mathrm{OH}^{-}$concentration in the SRPC and OPC paste specimens admixed with $0.8 \% \mathrm{Cl}^{-}$and various dosages of alkalinity is plotted in Figure 1. The $\mathrm{OH}^{-}$ concentration increased almost linearly with increasing alkalinity of cement. The $\mathrm{OH}^{-}$ concentrations in the OPC paste specimens were slightly more than those in the SRPC paste specimens up to an alkalinity of $1.2 \%$. However, they were similar when the alkalinity was $1.4 \%$.

Figure 2 depicts the chloride concentration in the SRPC and OPC paste specimens admixed with sodium chloride and different alkali contents. The chloride 
concentration increased with the alkalinity content in both the cements. The values in the SRPC paste specimens were slightly more than those in the OPC specimens up to an alkali content of $1 \%$. Beyond this alkalinity, the chloride concentration in both the cements was almost similar.

The $\mathrm{Cl}^{-} / \mathrm{OH}^{-}$ratio of the pore solution in the SRPC and OPC paste specimens admixed with $0.8 \% \mathrm{Cl}^{-}$and varying alkali contents is plotted in Figure 3. These values decreased with increasing alkali content of up to $0.8 \% \mathrm{Na}_{2} \mathrm{O}$, beyond which the $\mathrm{Cl}^{-} / \mathrm{OH}^{-}$increased slightly with increasing alkali content. The $\mathrm{Cl}^{-} / \mathrm{OH}^{-}$values in the SRPC paste specimens were slightly higher than those in the OPC paste specimens. The decrease in the $\mathrm{Cl}^{-} / \mathrm{OH}^{-}$ratio, with increasing alkalinity of cement, up to $0.8 \%$, may be attributed to an increase in the $\mathrm{OH}^{-}$concentration. Beyond $0.8 \%$ alkalinity, the increase in both $\mathrm{OH}^{-}$and $\mathrm{Cl}^{-}$is very marginal. This results in a slight increase in the $\mathrm{Cl}^{-} / \mathrm{OH}^{-}$ratio.

The sulfate concentration in the SRPC and OPC paste specimens is depicted in Figure 4. The sulfate concentration increased almost linearly with increasing alkali content of cement. The sulfate concentration in the control specimens $\left(\mathrm{Na}_{2} \mathrm{O}\right.$ equivalent of $0.4 \%$ ) was the same in both the cements. However, the sulfate concentration in the OPC specimens with other alkali contents was slightly higher than that in the SRPC specimens with similar alkali contents.

\subsection{Chloride-Induced Reinforcement Corrosion}

\subsubsection{Corrosion Potentials}

The corrosion potentials on steel in the SRPC concrete specimens admixed with alkalinity of $0.4,0.6,0.8,1.0,1.2$ and $1.4 \% \mathrm{Na}_{2} \mathrm{O}$ equivalent and exposed to $5 \% \mathrm{NaCl}$ 
solution containing similar alkalinity are plotted against the period of exposure in Figure 5. The corrosion potentials were initially high (less negative). However, they decreased with the period of exposure and then these values were more or less similar.

The corrosion potentials on steel in the OPC concrete specimens admixed with alkalinity of $0.4,0.6,0.8,1.0,1.2$ and $1.4 \% \mathrm{Na}_{2} \mathrm{O}$ and exposed to $5 \% \mathrm{NaCl}$ containing similar alkali contents are shown in Figure 6. These data also indicate a trend similar to that noted in the SRPC concrete specimens.

The corrosion potential curves, discussed in Figures 5 and 6, were utilized to evaluate the time to initiation of reinforcement corrosion based on the ASTM C876 criterion of $-270 \mathrm{mV} \mathrm{SCE}$. The time to initiation of reinforcement corrosion is plotted against alkalinity in Figure 7. These values, in both the cements increased with increasing alkali content of up to $0.8 \% \mathrm{Na}_{2} \mathrm{O}$. However, it decreased in the concrete specimens with alkalinity of more than $0.8 \% \mathrm{Na}_{2} \mathrm{O}$. This indicates that cement alkalinity of up to $0.8 \% \mathrm{Na}_{2} \mathrm{O}$ is beneficial from corrosion initiation point of view. However, a further increase in alkalinity does not indicate ant improvement in the corrosion-resistance of both OPC and SRPC.

\subsubsection{Corrosion Current Density}

The variation of $I_{\text {corr }}$ on steel in the SRPC concrete specimens with varying alkalinity is depicted in Figure 8 . The $\mathrm{I}_{\text {corr }}$ values were initially very low and similar up to 100 to 120 days of exposure in all the concrete specimens. After this time, the $\mathrm{I}_{\text {corr }}$ started to deviate and increased with increasing period of exposure. The $\mathrm{I}_{\text {corr }}$ on steel in the control specimens (cement with $\mathrm{Na}_{2} \mathrm{O}$ equivalent of $0.4 \%$ ) was more 
than that in the concrete specimens with higher alkalinity. However, the $\mathrm{I}_{\text {corr }}$ on steel in the concrete specimens with an alkalinity of $0.8 \%$ was the lowest. The $\mathrm{I}_{\text {corr }}$ on steel in the OPC concrete specimens with varying alkalinity is plotted against period of exposure in Figure 9. These data also exhibited a trend similar to that noted in the SRPC concrete specimens.

The $\mathrm{I}_{\text {corr }}$ on steel in the SRPC and OPC concrete specimens is plotted against alkalinity in Figure 10. The $\mathrm{I}_{\text {corr }}$ decreased with increasing alkali content of up to $0.8 \% \mathrm{Na}_{2} \mathrm{O}$, beyond which a slight increase in the $\mathrm{I}_{\text {corr }}$ was noted. These results together with those in Figure 7 indicate that the corrosion-resistance of concrete is improved up to an alkali content of $0.8 \%$. However, when the alkalinity is more than $0.8 \%$ this improvement is insignificant.

\section{Discussion}

\subsection{Pore Solution Chemistry}

The data in Figures 1 through 4 indicate that the $\mathrm{OH}^{-}, \mathrm{Cl}^{-}$and $\mathrm{SO}_{4}^{--}$concentrations in the pore solution increased almost linearly with increasing alkali content in the cement. The $\mathrm{OH}^{-}, \mathrm{Cl}^{-}$and $\mathrm{SO}_{4}^{--}$concentrations were almost similar in the SRPC and OPC paste specimens when the cement alkalinity was high. The increase in the $\mathrm{OH}^{-}$ concentration may be attributed to the $\mathrm{NaOH}$ added through the mix water. The increase in the chloride concentration with increasing alkalinity may be ascribed to the solubility of calcium chloro-aluminate hydrate (Friedel's salt) due to increasing alkalinity. The $\mathrm{SO}_{4}^{--}$concentration in the SRPC and OPC paste specimens also increased linearly with the alkalinity. This increase in the sulfate concentration may be attributed to the formation of $\mathrm{Na}_{2} \mathrm{SO}_{4}$ due to the reaction between the added sodium 
hydroxide and gypsum available in the cement. In other words, both calcium chloroaluminate and calcium sulpho-aluminate hydrates are unstable in a highly alkaline environment.

These results confirm the hypothesis presented in the work conducted by Dehwah [20] on the effect of alkalinity on chloride- and sulfate-binding of cement. An increase in the alkalinity of cement, particularly when the alkaline materials are added as contaminants, influences the chloride and sulfate binding of cements. While a decrease in chloride-binding of cements may accelerate reinforcement corrosion, the reduction in the sulfate binding is beneficial as it reduces the chances of delayed ettringite formation and hence reduce concrete deterioration due to sulfate attack. Another concern with regards the increase in alkalinity of cements is the acceleration of the alkali-aggregate reaction when reactive aggregates are used.

\subsection{Chloride-Induced Reinforcement Corrosion}

The data developed in the present study have indicated that the alkalinity of cement plays an important role in the kinetic of reinforcement corrosion. The corrosion potentials in the SRPC and OPC concrete specimens decreased with increasing alkalinity of cement. The time to initiation of reinforcement corrosion in both the cements also increased with increasing alkalinity content of up to $0.8 \%$. However, the time to initiation of reinforcement corrosion decreased with further increase in the cement alkalinity. Similarly, the $\mathrm{I}_{\text {corr }}$ on steel in the SRPC and OPC concrete specimens decreased with increasing cement alkalinity of up to $0.8 \%$. Beyond this alkalinity no appreciable change in the $\mathrm{I}_{\text {corr, }}$ was noted. However, the $\mathrm{I}_{\text {corr }}$ in the specimens with alkalinity of 1.0, 1.2 and 1.4 was also lower than that in the concrete specimens prepared with an alkalinity of 0.4 and $0.6 \%$. The results of 
this study indicate that, alkalinity improves the resistance to reinforcement corrosion of both SRPC and OPC, the highest improvement occurring when the alkalinity was $0.8 \%$.

The improvement in corrosion-resistance of concrete due to increasing alkalinity may be attributed to an increase in the $\mathrm{pH}$ of the pore solution, which stabilizes the protective layer on the steel bar. However, a slight decrease in the corrosionresistance was noted when alkalinity was more than $0.8 \%$. This may be attributed to a decrease in the chloride-binding due to high alkalinity. Goni and Andrade [21] reported that as the alkalinity increases the $\mathrm{pH}$ also increases and the $\mathrm{I}_{\text {corr }}$ decreases.

The other important factor to which the corrosion resistance improvement may be attributed, is the $\mathrm{Cl}^{-} / \mathrm{OH}^{-}$ratio of the pore solution. The $\mathrm{Cl}^{-} / \mathrm{OH}^{-}$ratio of the pore solution in the cement paste specimens admixed with sodium chloride and alkalinity decreased with increasing alkali content of cement up to $0.8 \% \mathrm{Na}_{2} \mathrm{O}$, and then increased slightly with increasing alkali content up to $1.4 \% \mathrm{Na}_{2} \mathrm{O}$. The $\mathrm{I}_{\text {corr }}$ exhibited a similar behavior. The results of the $\mathrm{Cl}^{-} / \mathrm{OH}^{-}$ratio of the pore solution together with those reported by Goni and Andrade [21] support the results of the $\mathrm{I}_{\text {corr }}$ obtained in this study. Further, the concrete specimens were investigated visually by splitting them and the bars were taken out which indicated that the corrosion on steel bars in both cements exhibited a trend similar to that noted in the $\mathrm{Cl}^{-} / \mathrm{OH}^{-}$ratio of the pore solution in Figure 3. The corrosion was the highest in the control specimens while it was the lowest in the specimens admixed with $0.8 \% \mathrm{Na}_{2} \mathrm{O}$ equivalent.

A maximum limit of $0.6 \%$ cement alkalinity, expressed as $\mathrm{Na}_{2} \mathrm{O}$ equivalent, is normally imposed by many international standards, such as ASTM and BS. This 
limitation is purely adopted to avoid alkali-aggregate reaction, when alkali-reactive aggregates are utilized in concrete. The results of this study show that the alkali content can be increased to $0.8 \%$, to enhance the corrosion-resistance of concrete. This will be beneficial if it is known that the aggregates are not reactive. Therefore, the limits on alkali content in cement should be case specific as suggested below:

Limitations on cement alkalinity ( $\mathrm{Na}_{2} \mathrm{O}$ equivalent):

Potentially alkali-reactive aggregate: $<0.6 \%$

Inert aggregate: 0.6 to $0.8 \%$

\section{Conclusions}

The $\mathrm{OH}^{-}, \mathrm{Cl}^{-}$, and $\mathrm{SO}_{4}^{--}$concentrations in the pore solution of the SRPC and OPC increased with increasing alkali contents of cement. The increase in the chloride and sulfate concentration due to increasing alkalinity indicates that both calcium chloroaluminate and calcium sulphoaluminate hydrates are not stable at high alkalinity. The chloride-binding capacity was influenced significantly by the cement alkalinity. The chloride concentration increased with increasing alkali content of cement. The $\mathrm{Cl}^{-}$ $/ \mathrm{OH}^{-}$ratio decreased with increasing alkali content up to $0.8 \% \mathrm{Na}_{2} \mathrm{O}$ and then increased with further increase in the alkalinity.

The time-to-initiation of reinforcement corrosion in the SRPC and OPC concretes increased with increasing alkalinity of up to $0.8 \% \mathrm{Na}_{2} \mathrm{O}$ equivalent. However, when the alkalinity was more than $0.8 \% \mathrm{Na}_{2} \mathrm{O}$ equivalent, a decrease in the time-toinitiation of reinforcement corrosion was noted. 
The $\mathrm{I}_{\text {corr }}$ on steel in the SRPC and OPC concrete specimens, with varying alkali content, was initially very low and similar in all the specimens. However, it changed with alkali content and period of exposure. The $\mathrm{I}_{\text {corr }}$ was the lowest in both SRPC and OPC concrete specimens when the alkalinity was $0.8 \% \mathrm{Na}_{2} \mathrm{O}$ equivalent. However, it increased with further increase in the alkalinity.

The corrosion resistance of SRPC and OPC concrete specimens improved with increasing alkali content of cement. However, the highest improvement was noted when the alkalinity was $0.8 \% \mathrm{Na}_{2} \mathrm{O}$ equivalent. The alkali content of cement can be increased to $0.8 \%\left(\mathrm{Na}_{2} \mathrm{O}\right.$ equivalent) to increase the corrosion-resistance of concrete. However, the present limit of $0.6 \%$ should be adhered to when it is expected that the aggregates are alkali-reactive.

\section{Acknowledgments}

The authors acknowledge the support provided by King Fahd University of Petroleum and Minerals, Dhahran, Saudi Arabia and the Department of Civil and Building Engineering, Loughborough University, Leicestershire, UK.

\section{REFERENCES}

1. Hussain, S. E., Mechanisms of High Durability Performance of Plain and Blended Cements, Ph.D. Dissertation, King Fahd University of Petroleum and Minerals, Dhahran, Saudi Arabia, August 1991.

2. Talib, A. Y., Durability performance of Silica Fume Cement Concrete in the Arabian Gulf Environment, Ph.D. Thesis, The Catholic University of America, Washington D. C., Oct. 1996.

3. Page, C. L. and Vennesland, O., "Pore Solution Composition and Chloride Binding Capacity of Silica-Fume Cement Pastes," Materials and Structures, Vol. 16, No. 91, 1983, pp. 19-25.

4. Gunkel, P., "Chloridgehalte Ausgeprebter Porenlosungen", International Mitteilungen, FEhs 1983.

5. Tritthart, J., "Chloride Binding in Cement, II: The Influence of the Hydroxide Concentration in the Pore Solution of Hardened Cement Paste on Chloride 
Binding," Cement and Concrete Research

6. Hausmann, D. A., "Steel Corrosion in Concrete, How Does it Occur?," Materials Protection, Vol. 6, November 1967, pp. 19-23.

7. Gouda, V. K., "Corrosion and Corrosion Inhibition of Reinforcing Steel: I. Immersed in Alkaline Solution," British Corrosion Journal, Vol. 5, 1970, pp. 198-203.

8. Lambert, P., Page, C. L. and Vassie, P. R. W., "Investigations of Reinforcement Corrosion. 2. Electrochemical Monitoring of Steel in ChlorideContaminated Concrete," Materials and Structures, 24, 1991, pp. 351-358.

9. Kayyali, O. A., and Haque, M. N., "The $\mathrm{Cl} / \mathrm{OH}$ ratio in ChlorideContaminated Concrete: A most Important Criterion," Magazine of Concrete Research, Vol. 47, No. 172, 1995, pp. 235-242.

10. Mangat, P. S. and Molloy, B. T., "Influence of PFA, Slag and Microsilica on Chloride Induced Corrosion of Reinforcement in Concrete," Cement and Concrete Research, Vol. 21, No. 5, 1991, pp. 819-834.

11. Al-Amoudi, O. S. B., Rasheeduzzafar, Maslehuddin M., and Abduljauwad, S. N., "Durability Evaluation of Plain and Blended Cements in Aggressive Media," Proceedings, 9th International Congress on the Chemistry of Cement, 1992, Vol. 5, pp. 438-444.

12. Arya, C., Buenfeld, N. R. and Newman, J. B., "Assessment of Simple Methods of Determining the Free Chloride Ion Content of Cement Paste," Cement and Concrete Research, Vol. 17, 1987, pp. 907-918.

13. Longuet, P., Burglen, L. and Zelwer, A., "Liquid Phase of Hydrated Cement," Review of Materials Constructions, No. 676, 1973, pp. 35-41.

14. Barneyback, R. S. and Diamond, S., "Expression and Analysis of Pore Fluid from Hardened Cements and Mortars," Cement and Concrete Research, Vol. 11, 1981, pp. 279-285.

15. Vogel, A. I., A Textbook of Quantitative Inorganic Analysis, 4th Edition, Revised by J. Bassett, Longman, London, 1978, p. 754

16. Standard Methods for the Examination of Water and Wastewater, 16th Edition, American Public Health Association, Washington, 1985.

17. Stern, M. and Geary, A. L., "Electrochemical Polarization, No. 1, Theoretical Analysis of the Shape of Polarization Curves," Journal of Electrochemical Society, Vol. 104, No. 1, Jan. 1957, p. 56.

18. Andrade, C., Castelo, V., Alonso, C. and Gonzalez, J. A., "Determination of the Corrosion Rate of Steel Embedded in Concrete," ASTM Special Technical Publication STP 906, Philadelphia, 1986, p. 43. 
19. Dehwah, H. A. F., Basunbul, I.A., Maslehuddin, M., Al-Sulaimani, G.J., and Baluch, M., "Durability Performance of Repaired Reinforced Concrete Beams," , ACI Materials Journal, Vol.91 No.2 March-April 1994, pp.167172.

20. Dehwah, H. A. F., " Influence of Cement Composition on Concrete Durability in Chloride-Sulfate Environments, Ph.D. Thesis, Loughborough University, Loughborough, UK.

21. Goni, S. and Andrade, C., "Synthetic Concrete Pore Solution Chemistry and Rebar Corrosion rate in the presence of Chlorides," Cement and Concrete Research, Vol. 20, No. 4, 1990, pp. 525-539. 


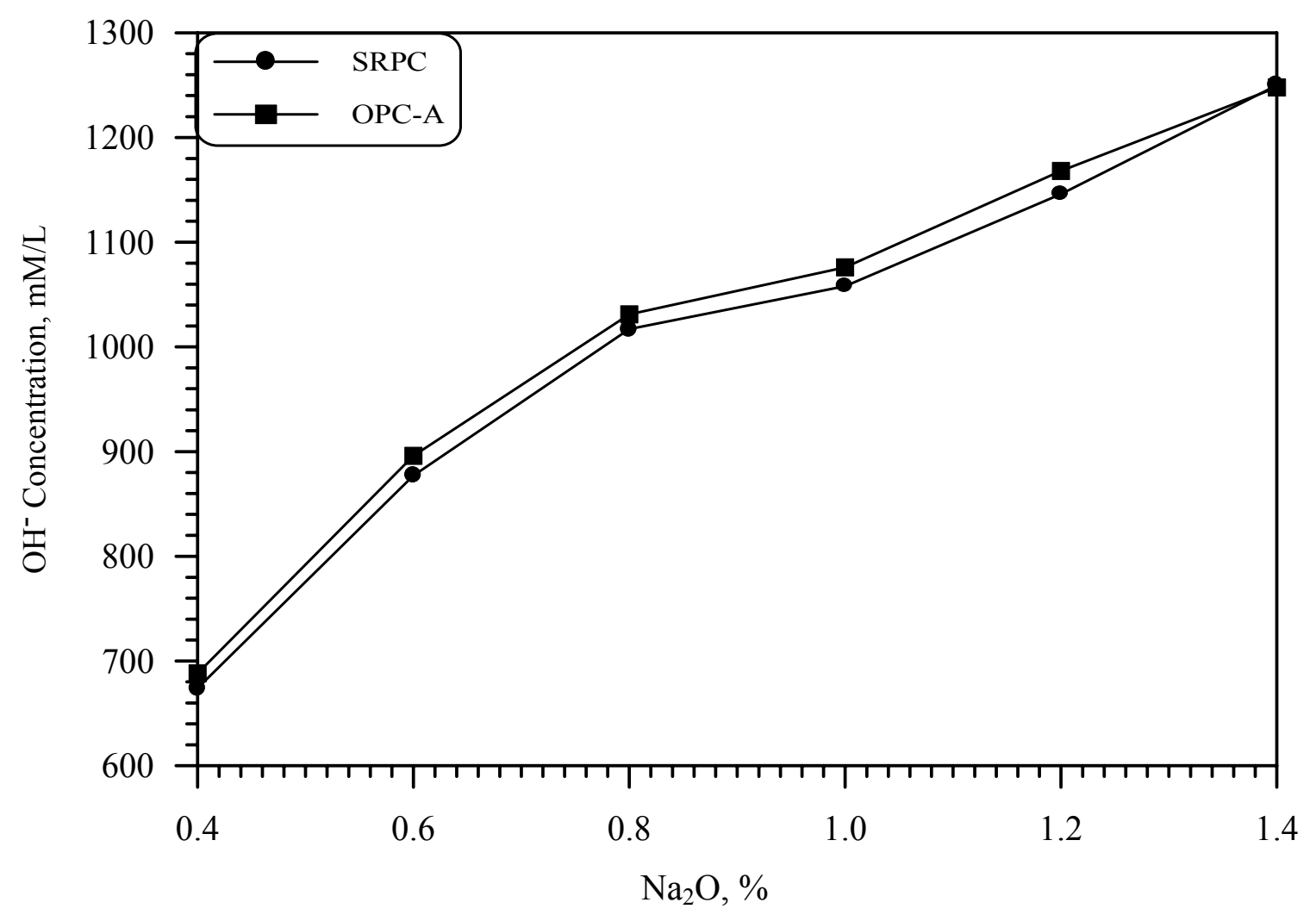

Figure 1: Variation of $\mathrm{OH}^{-}$concentration with alkalinity $\left(\mathrm{Na}_{2} \mathrm{O}\right.$ equivalent) in the SRPC and PC paste specimens.

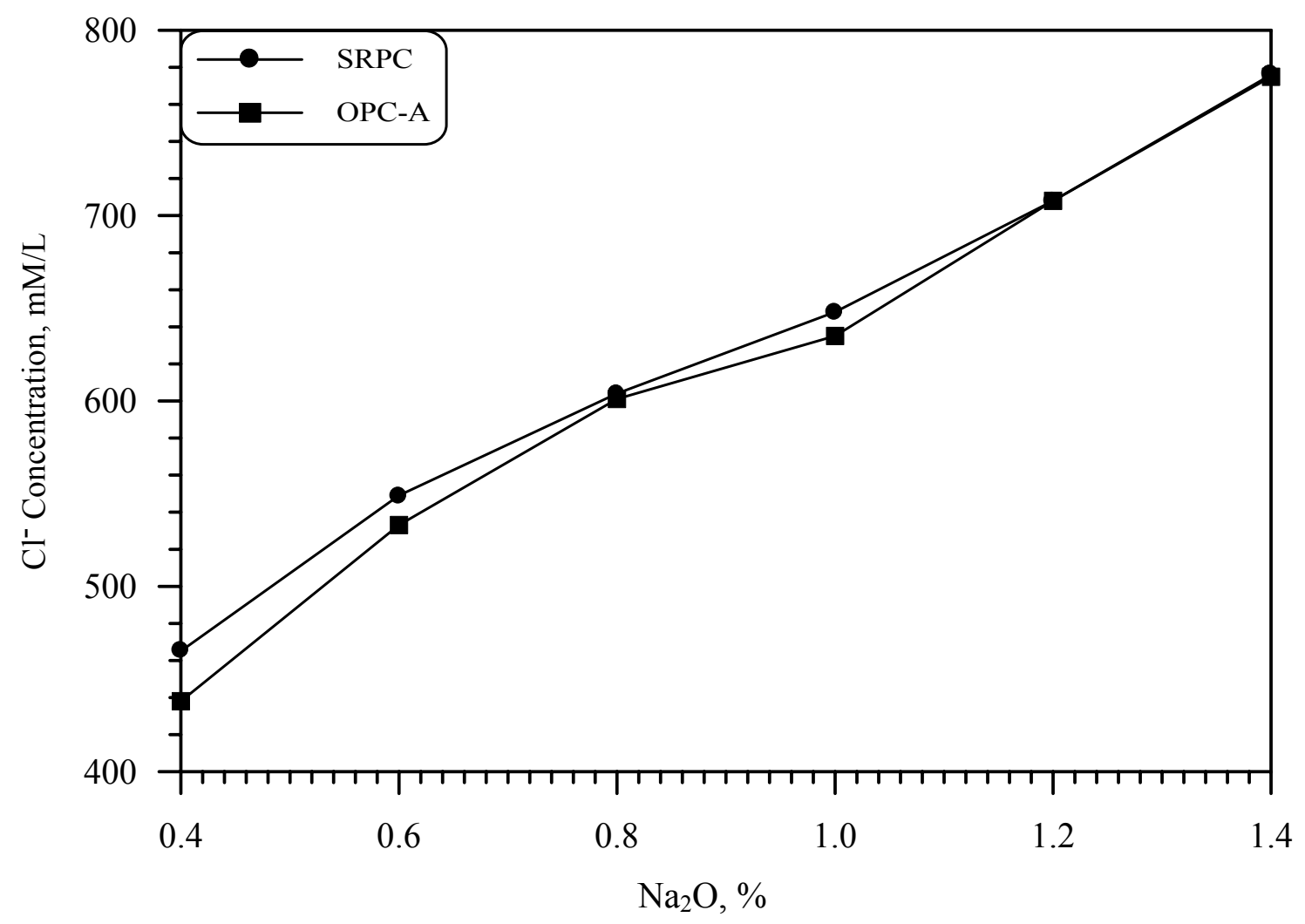

Figure 2: Variation of $\mathrm{Cl}^{-}$concentration with alkalinity $\left(\mathrm{Na}_{2} \mathrm{O}\right.$ equivalent) in the SRPC and PC paste specimens. 


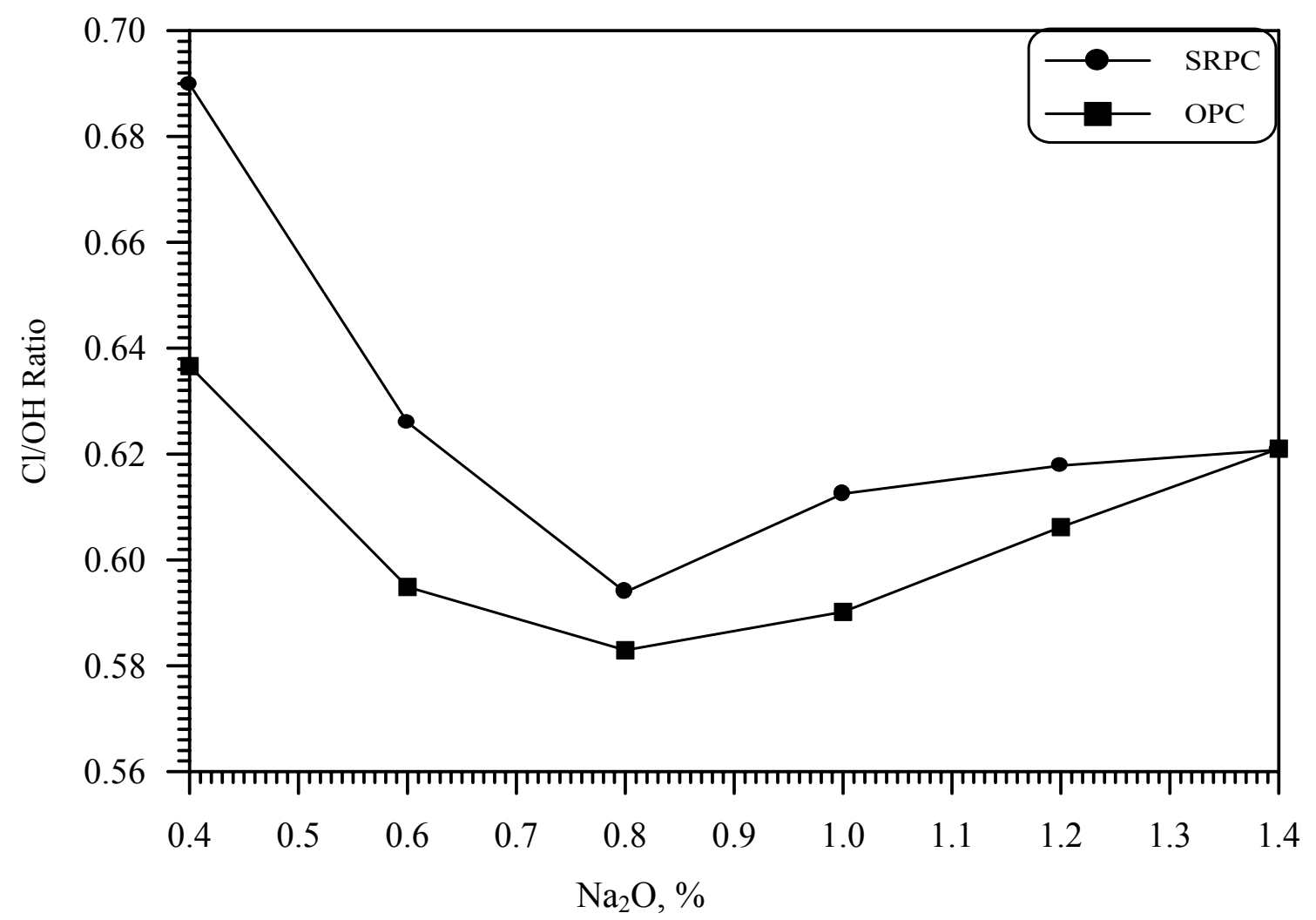

Figure 3: Variation of $\mathrm{Cl}^{-} / \mathrm{OH}^{-}$with alkalinity $\left(\mathrm{Na}_{2} \mathrm{O}\right.$ equivalent) in the $\mathrm{SRPC}$ and $\mathrm{PC}$ paste specimens.

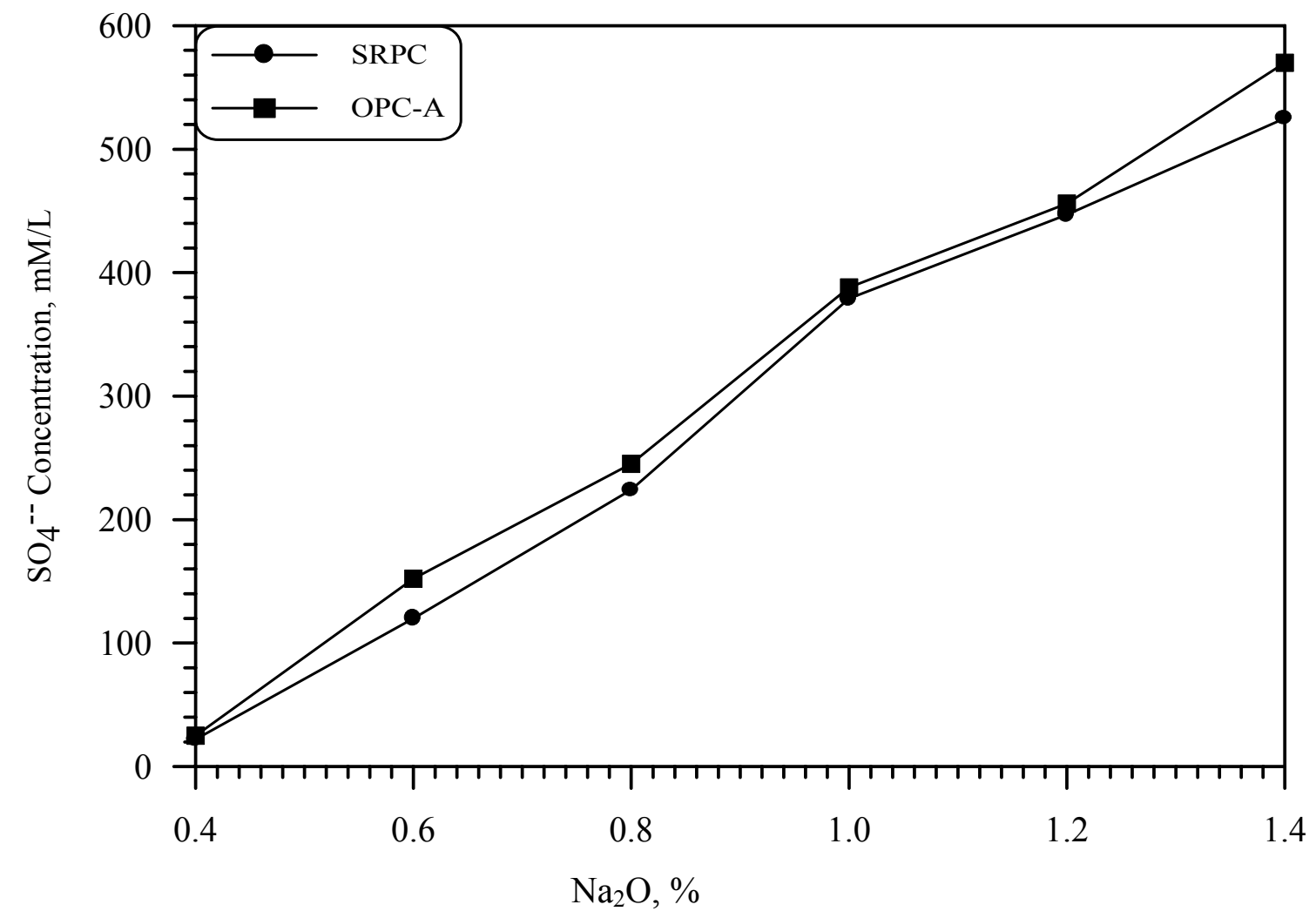

Figure 4: Variation of $\mathrm{SO}_{4}^{--}$concentration with alkalinity $\left(\mathrm{Na}_{2} \mathrm{O}\right.$ equivalent) in the SRPC and PC paste specimens. 


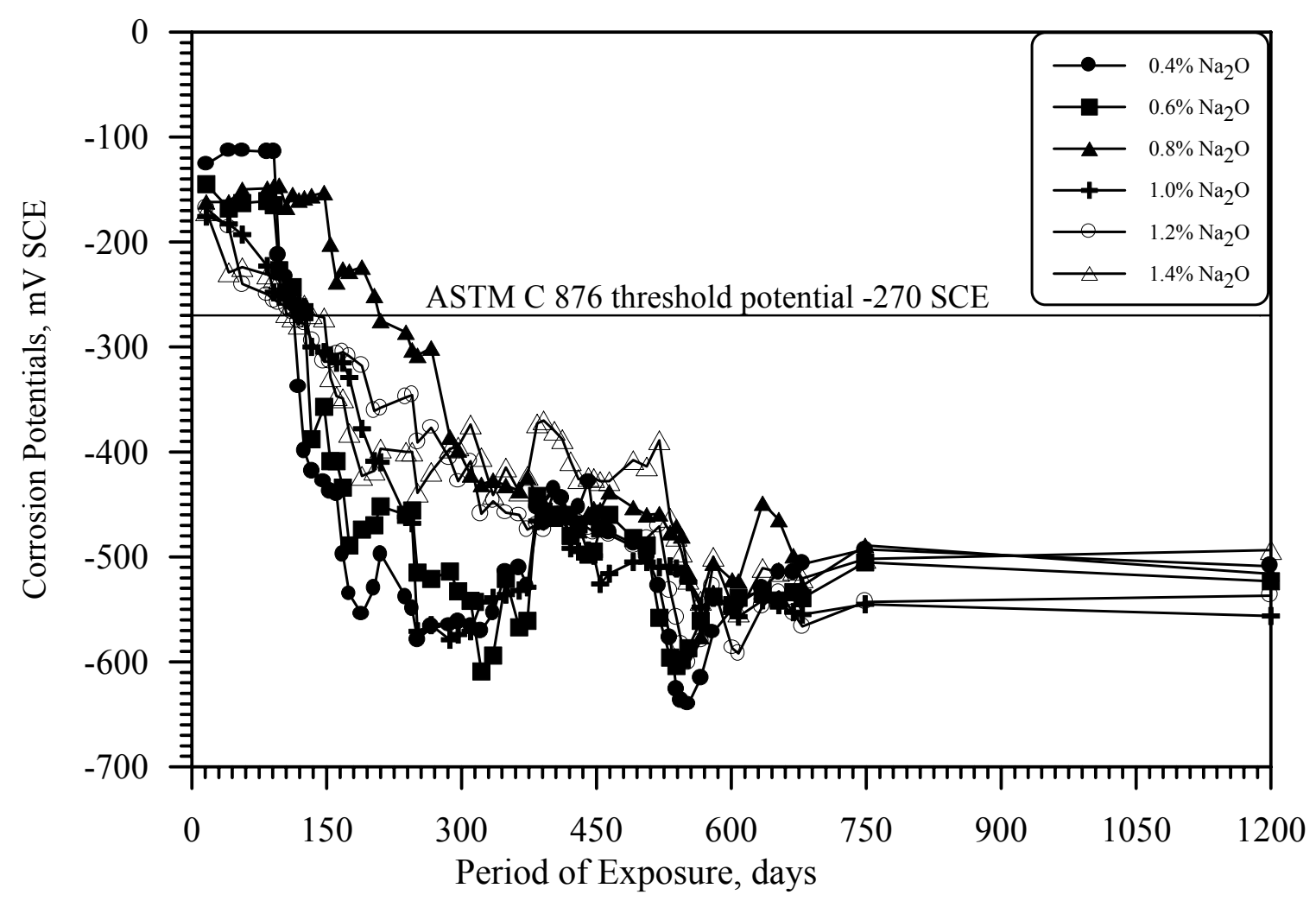

Figure 5: Variation of corrosion potentials with time on steel in the SRPC concrete specimens exposed to $5 \% \mathrm{NaCl}$ plus solution admixed with $\mathrm{Na}_{2} \mathrm{O}$.

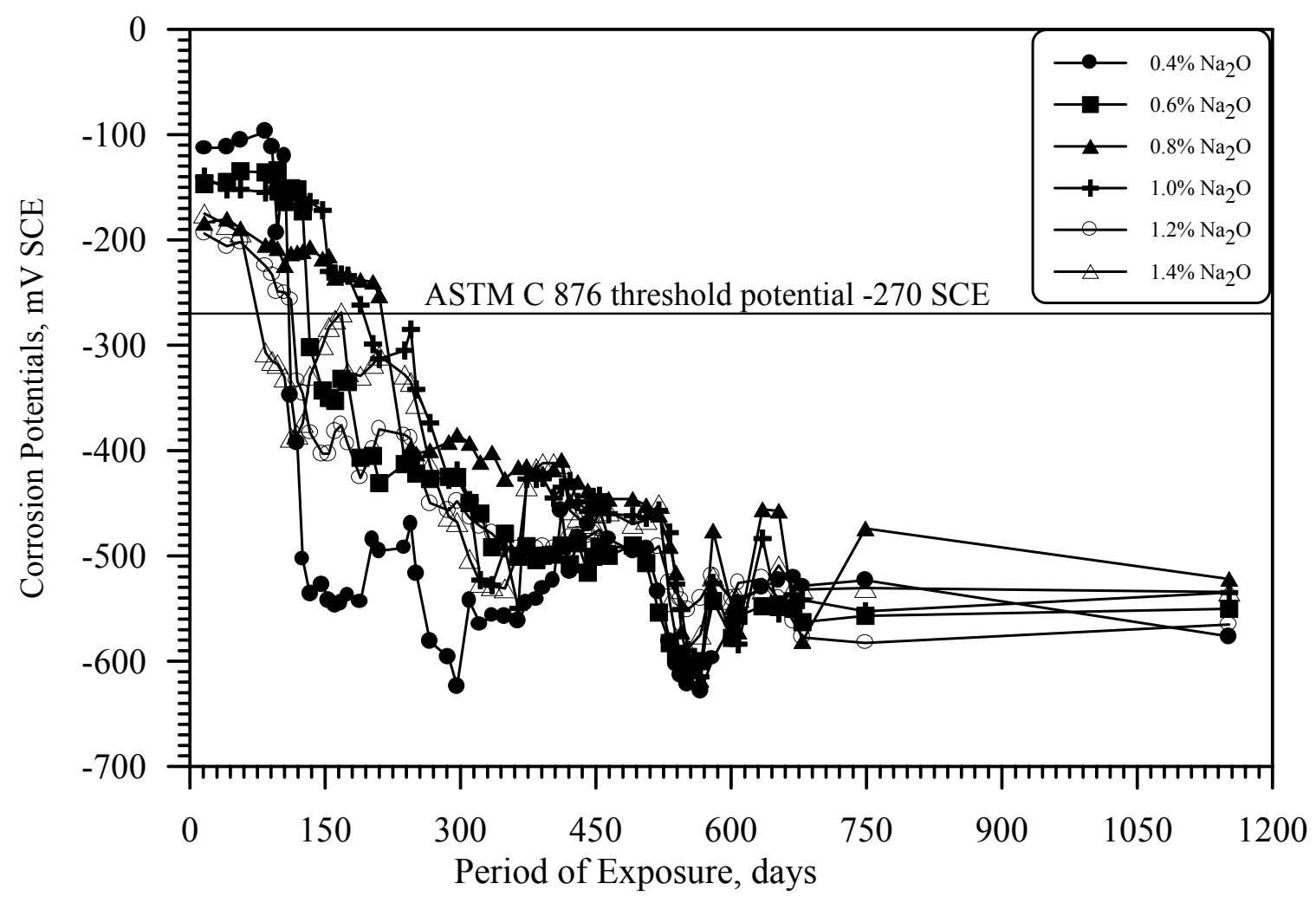

Figure 6: Variation of corrosion potentials with time on steel in the $\mathrm{PC}$ concrete specimens exposed to $5 \% \mathrm{NaCl}$ plus solution admixed with $\mathrm{Na}_{2} \mathrm{O}$. 


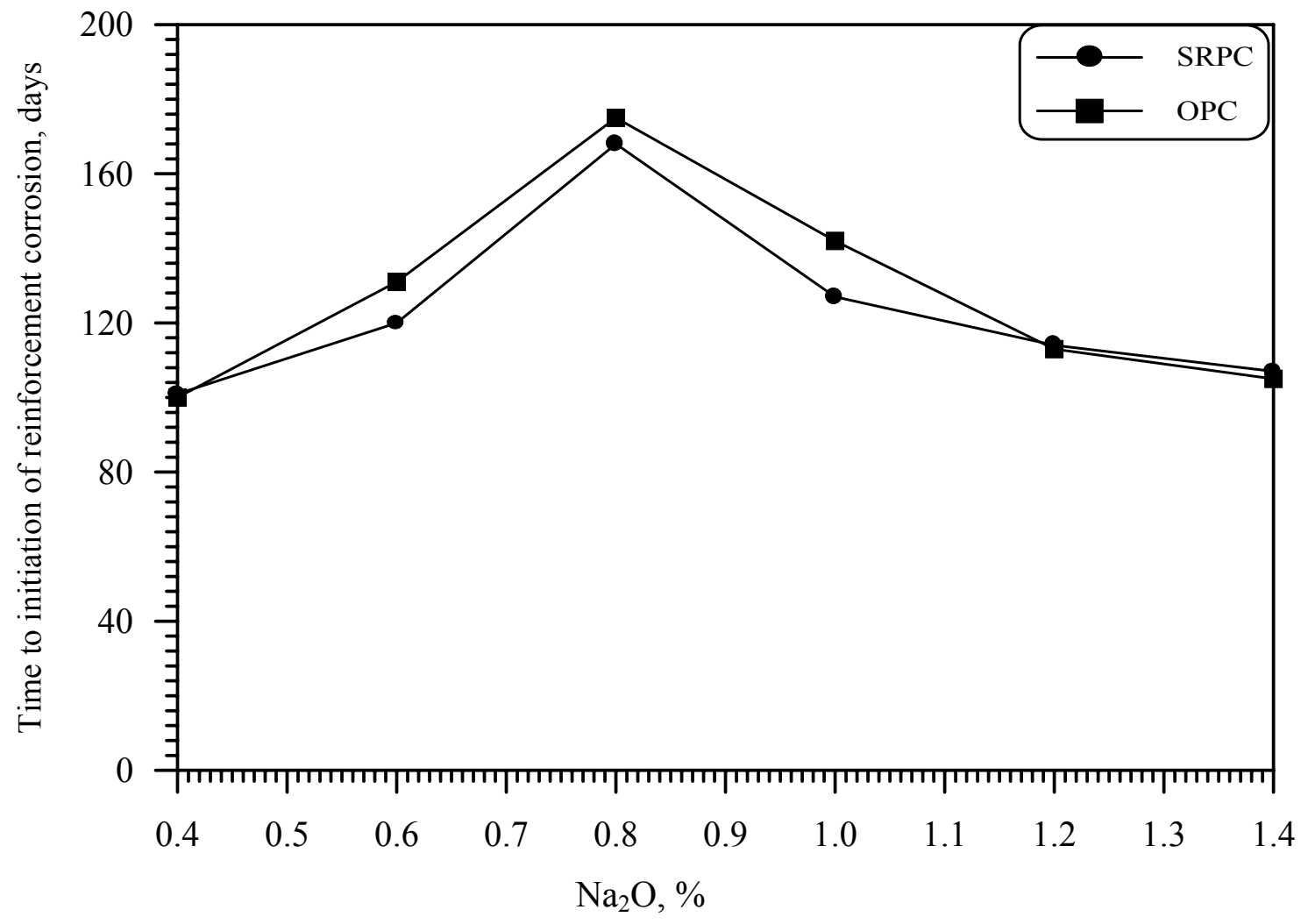

Figure 7: Variation of time to initiation of reinforcement corrosion with alkalinity in the SRPC and PC concrete specimens.

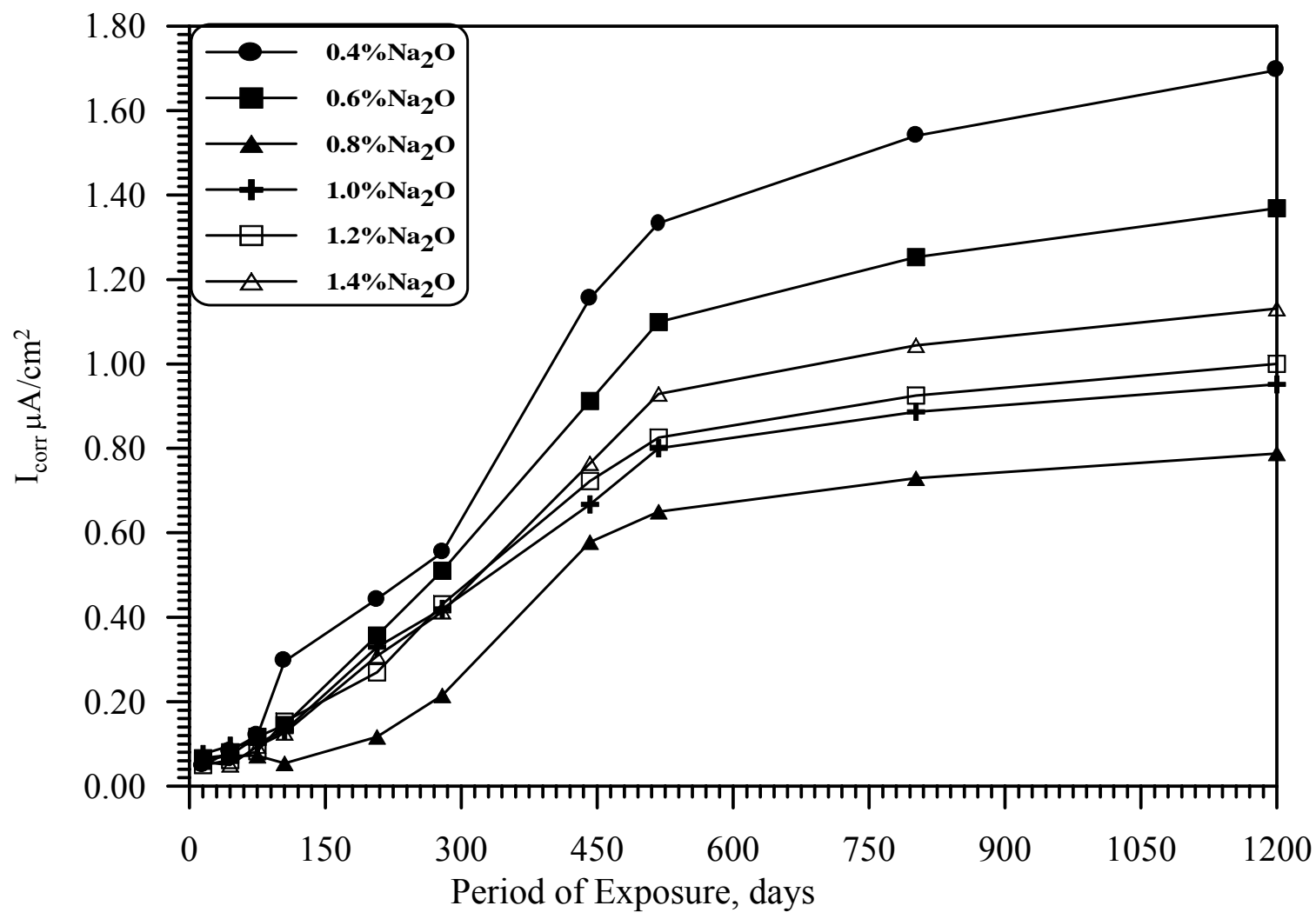

Figure 8: Variation of $\mathrm{I}_{\text {corr }}$ with period of exposure in the SRPC concrete specimens exposed to $5 \% \mathrm{NaCl}$ solution admixed with $\mathrm{Na}_{2} \mathrm{O}$. 


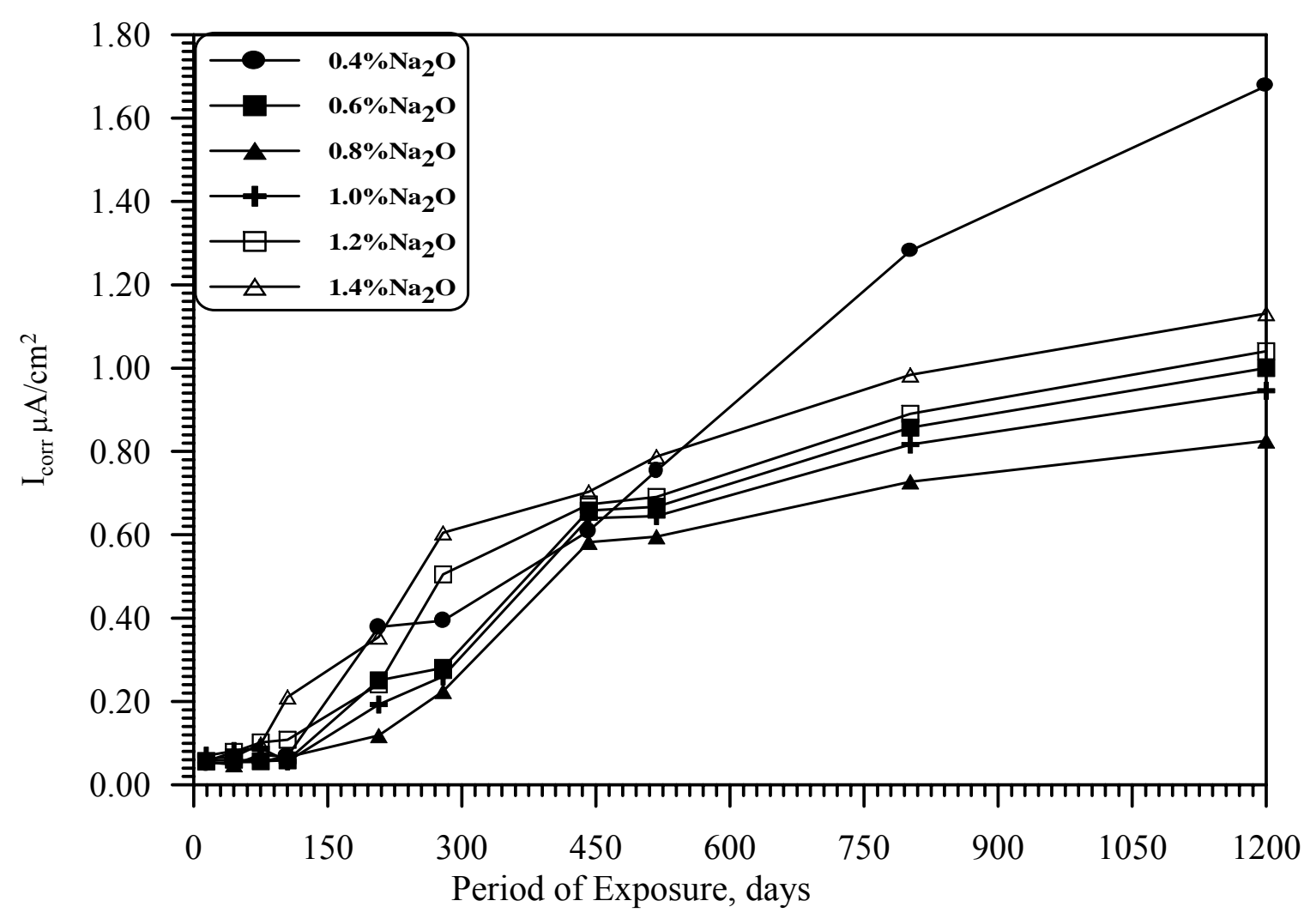

Figure 9: Variation of $\mathrm{I}_{\text {corr }}$ with period of exposure in the SRPC concrete specimens exposed to $5 \% \mathrm{NaCl}$ solution admixed with $\mathrm{Na}_{2} \mathrm{O}$.

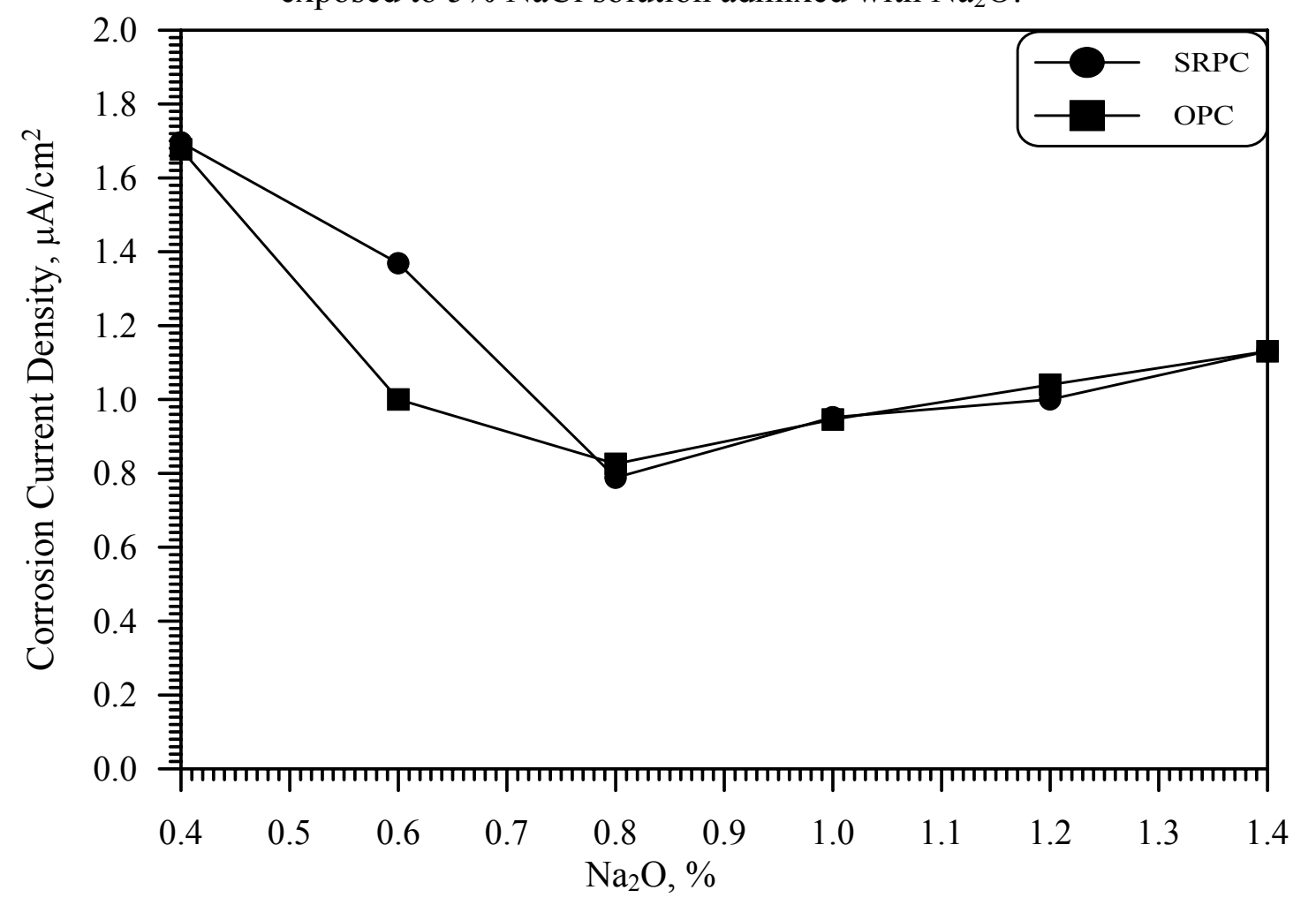

Figure 10: Variation of $\mathrm{I}_{\text {corr }}$ with alkalinity $\left(\mathrm{Na}_{2} \mathrm{O}\right.$ equivalent $)$ in the SRPC and PC concrete specimens 
Table 1: Chemical composition of cements.

\begin{tabular}{|c|c|c|}
\hline $\begin{array}{c}\text { Constituent } \\
(\mathrm{Wt} \%)\end{array}$ & SRPC $^{1}$ & $\mathrm{PC}^{2}$ \\
\hline $\mathrm{SiO}_{2}$ & 22.00 & 20.52 \\
\hline $\mathrm{Al}_{2} \mathrm{O}_{3}$ & 4.08 & 5.64 \\
\hline $\mathrm{Fe}_{2} \mathrm{O}_{3}$ & 4.24 & 3.80 \\
\hline $\mathrm{CaO}$ & 64.07 & 64.35 \\
\hline $\mathrm{MgO} \mathrm{SO}_{3}$ & 2.21 & 2.11 \\
\hline $\mathrm{Loss} \mathrm{on} \mathrm{ignition}$ & 0.80 & 0.70 \\
\hline $\mathrm{K}_{2} \mathrm{O}$ & 0.31 & 0.36 \\
\hline $\mathrm{Na}_{2} \mathrm{O}$ & 0.21 & 0.19 \\
\hline $\mathrm{Na}_{2} \mathrm{O}$ equivalent & 0.41 & 0.43 \\
\hline $\mathrm{C}_{3} \mathrm{~S}$ & 54.57 & 56.70 \\
\hline $\mathrm{C}_{2} \mathrm{~S}$ & 21.91 & 16.05 \\
\hline $\mathrm{C}_{3} \mathrm{~A}$ & 3.64 & 8.52 \\
\hline $\mathrm{C}_{4} \mathrm{AF}$ & 12.90 & 11.56 \\
\hline
\end{tabular}

1 Sulfate-resisting Portland cement $\left(\mathrm{C}_{3} \mathrm{~A}: 3.6 \%\right)$

2 Portland cement $\left(\mathrm{C}_{3} \mathrm{~A}: 8.5 \%\right)$ 
Table 2: Composition of the Test Solution

\begin{tabular}{|c|l|}
\hline Group & Composition of exposure solution \\
\hline 1 & $5 \% \mathrm{NaCl}+0.4 \% \mathrm{Na} 2 \mathrm{O}$ equivalent (control) \\
\hline 2 & $5 \% \mathrm{NaCl}+0.6 \% \mathrm{Na} 2 \mathrm{O}$ equivalent \\
\hline 3 & $5 \% \mathrm{NaCl}+0.8 \% \mathrm{Na}_{2} \mathrm{O}$ equivalent \\
\hline 4 & $5 \% \mathrm{NaCl}+1.0 \% \mathrm{Na}_{2} \mathrm{O}$ equivalent \\
\hline 5 & $5 \% \mathrm{NaCl}+1.2 \% \mathrm{Na} 2 \mathrm{O}$ equivalent \\
\hline 6 & $5 \% \mathrm{NaCl}+1.4 \% \mathrm{Na} 2 \mathrm{O}$ equivalent \\
\hline
\end{tabular}

Table 3. Time to initiation of reinforcement corrosion in concrete specimens with varying alkalinity.

\begin{tabular}{|c|c|c|}
\hline \multirow{2}{*}{ Exposure solution } & \multicolumn{2}{|c|}{$\begin{array}{c}\text { Time-to-initiation of reinforcement } \\
\text { corrosion, Days }\end{array}$} \\
\cline { 2 - 3 } & SRPC & PC \\
\hline $5 \% \mathrm{NaCl}+0.4 \% \mathrm{Na}_{2} \mathrm{O}$ & 101 & 110 \\
\hline $5 \% \mathrm{NaCl}+0.6 \% \mathrm{Na}_{2} \mathrm{O}$ & 125 & 131 \\
\hline $5 \% \mathrm{NaCl}+0.8 \% \mathrm{Na}_{2} \mathrm{O}$ & 168 & 175 \\
\hline $5 \% \mathrm{NaCl}+1.0 \% \mathrm{Na}_{2} \mathrm{O}$ & 127 & 135 \\
\hline $5 \% \mathrm{NaCl}+1.2 \% \mathrm{Na}_{2} \mathrm{O}$ & 114 & 113 \\
\hline $5 \% \mathrm{NaCl}+1.4 \% \mathrm{Na}_{2} \mathrm{O}$ & 100 & 105 \\
\hline
\end{tabular}

